\title{
Comparisons of stakeholders' perception towards the sustainable tourism development and its impacts in Shkodra Region (Albania)
}

Drita Kruja*

Alkida Hasaj*

Received: December 2009| Accepted: March 2010

\section{Abstract}

Tourism is one of the world's fastest growing industries, and has been identified as a means of generating national income in less industrialized economies. Like other countries, Albania has promoted tourism as a major source of national income.

The tourism industry in Albania currently focuses on coastal areas, rather than on the unique features that set this country apart from its neighbors. Albania's natural features have the potential to attract tourists seeking ecological and cultural experiences. Thoughtful, sustainable development of these resources could enhance community livelihoods throughout Albania.

The purpose of this study was to discover if differences in perceptions of sustainable tourism development and principles in Shkodra Region existed between four stakeholder groups: residents, entrepreneurs, government officials, and tourists.

Data were collected from stakeholders using a self competed questionnaire, which included Likert-style questions inquiring about attitudes and perceptions of sustainable tourism development in the community.

The data gathered illustrate that the perception of sustainable tourism principles varies considerably among stakeholder groups. As a distinct stakeholder group, the majority of local residents generally were welcoming of tourism.

Key words: sustainable tourism, stakeholders, perceptions, Shkodra Region.

* Department of Tourism, Economy Faculty, University of Shkodra “Luigj Gurakuqi”, Albania dritakruja@yahoo.com; alkidahasaj@yahoo.com 


\section{Introduction}

Sustainability has become an important topic and concept in relation to tourism planning and development (Inskeep I99I; Southgate \& Sharpley 2002; Yuksel, Bramwell \& Yuksel 1999).

This focus is in part due to tourism's inherent nature to have both positive and negative effects on a community, the economy, and the environment. Gunn (I994) stated that there is no other form of development "that has so many far-reaching tentacles as doe's tourism” (p.I6). Choi \& Sirakaya (2006), Inskeep (I99I), and McCool (I995) furthered this idea indicating that, if tourism development was planned improperly it could destroy the very resources (e.g. economic, environmental, and social) that are the foundation of tourism in a community.

So, for tourism development to be successful and beneficial to a community, it must be planned and managed responsibly (Butler et al., I998; De Oliveira, 2003; Inskeep, I99I; Martin, I995; Southgate and Sharpley, 2002; Yuksel et al., 1999). Similarly, communities that use or plan to use tourism as an economic development tool to diversify their economy must develop policies for the sustainable development of the community (De Oliveira, 2003; Pucako and Ratz, 2000; Southgate and Sharpley, 2002; Yuksel et al., I999).

One main key to the success and implementation of sustainable tourism development in a community is the support of stakeholders, (e.g. example citizens, entrepreneurs, and community leaders) (Gunn 1994).

A stakeholder is identified as "any group or individual who can affect or is affected by" tourism development in an area (Freeman I984, p 46). The focus on more stakeholder participation emphasizes its ability to handles multiple perceived issues. The first issue is that tourism development decisions are made from the top down, where "experts" make decisions. Often decisions made in this manner are perceived by the local community as not being reflective of community interests and opinions. The second issue is that the decision making system is perceived to have competing interests within it, and, therefore, the decisions made are again not reflective of the public's interests (Beierle \& Konisky 2000). Furthermore, participation can potentially lead to the avoidance of major conflicts between stakeholder groups (Healey I998). Robson \& Robson (I996, p.534) propose that stakeholder management holds the potential to help maintain the balance between tourism activity and social and environmental concerns and thus, provide a fundamental framework within which sustainable tourism development can be delivered.

Much of the research that have been done in the past, investigate only the complex relationship between stakeholders and tourism on individual stakeholder groups; residents, visitors, business owners, or government officials; and their perceptions and attitudes (Andereck and Vogt, 2000; Brunt and Courtney, I999; Long et al., I990; Martin, I995; Mathieson and Wall, I982; Murphy, I985; Pizam et al., 2000). Hardy and Beeton (2OOI) stress the need for studies that look at multiple stakeholder groups and compare them based on their interests.

So, the principal aim of this research is:

"To discover if differences in perceptions of sustainable tourism development and principles in Shkodra Region existed between four stakeholder groups"

In order to facilitate this aim, the research aspires towards a number of key objectives and develops a case study approach, in which the Shkodra Region becomes the primary focus. 


\section{Stakeholders in Sustainable Tourism Development and their Roles}

Contemporary tourism is much more than just going on holiday (Holden, 20OI, p.5); it is a truly global activity that accounts for the single largest peaceful movement of people across cultural boundaries in the history of the world (Lett, I989, p.277)

No one can deny the remarkable expansion of global tourism that occurred during the latter half of the 20th century (Weaver, 2000), as a spectacular boom in the I95Os witnessed an exploding horizon of what was set to become the world's fastest growing industry. In spite of this, the UNEP \& WTO (2005) warn that tourism presents a considerable challenge to the local environment and communities on which it is dependent. As the Asian saying states:

"Tourism is like fire: you can cook your dinner on it, but if you're not careful it will burn your house down." (WWF, 2004)

For a host community, investment in a tourism industry can have certain advantages over others. Tourism is often viewed as an environmentally friendly industry compared to other industries such as manufacturing (Davis and Morais, 2004; Wilson et al., 2OOI). As an economic development strategy, tourism can be less costly and easier to establish than other economic development strategies, because it is for the most part dependent upon the infrastructure already present in these communities.

Although tourism has the potential to provide many financial and environmental benefits to a community — especially those experiencing a decline in other industries — it is by no means a panacea. But in some cases, tourism has the potential to create negative impacts.

During the I980s, at a time when green consciousness was the precursor in developmental thought, tourism research began to recognize these detrimental impacts and emphatically articulate the need for a new, more socially and ecologically benign alternative to mass tourism (Fennel, 2003, p.4; Berry \& Ladkin, I997, p.434). In trying to be different (or better?) alternative tourism has come to encompass a whole range of synonyms. For example 'soft', 'eco-', 'responsible' and 'green' tourism all purport to circumvent economic and technical necessities alone, emphasising the demand for an unspoiled environment and a consideration of the needs of local people.

Consequently, 'sustainability' has seemingly been endorsed as the new ideal to arrest tourism's damaging effects (Godfrey, I998, p. 2I3).

In an effort to incorporate sustainable concepts into tourism development, many authors have attempted to define or describe sustainable tourism development (Gunn 1994; Hardy \& Beeton 2OOI; Ioannides I995; Robson \& Robson I996; WTO I998), but there is no universally accepted definition. The definition applied most often by tourism planners and in the tourism research literature was developed by the World Tourism Organization (WTO). The definition is as follows: Sustainable tourism development meets the needs of the present tourists and host Regions while protecting and enhancing opportunities for the future. It is envisaged as leading to management of all resources in such a way that economic, social, and aesthetic needs can be fulfilled while maintaining cultural integrity, essential ecology processes, biological diversity, and life support systems (p 2I, I998).

The WTO' s conceptualization of sustainable tourism development addresses six main principles: (I) a high level of tourist satisfaction, (2) optimal use of environmental resources, (3) respecting the socio-cultural authenticity of host communities, (4) providing socio-economic benefits to all stakeholders, (5) constant monitoring of impacts, and (6) informed participation of all relevant stakeholders, as well as strong political leadership. 
Who should be involved in the sustainable tourism development process? Based on the definitions that are used for sustainability and sustainable tourism development four distinct groups are identified; the present visitors, future visitors, present host community, and future host community. The host community can be further divided into residents, business owners, and government officials. The management view of the stakeholder theory indicates that all stakeholder groups should be involved in the entire tourism development process.

The concept of stakeholder participation has its roots in the business management and public administration literatures. Stakeholder participation was not prominent in the management literature until 1984 when Freeman wrote Strategic Management: A Stakeholder Approach. Freeman (I984) defined a stakeholder as "any group or individual who can affect or is affected by the achievement of the organizations objectives" (p 46). Donaldson and Preston (I995) refined this definition, stating that to be identified as a stakeholder, the group or individual must have a legitimate interest in the organization. Since Freeman's first work on stakeholder theory, stakeholder theory has been incorporated into business management literature (Clarkson I995; Donaldson \& Preston I995; Jones I995; Stoney \& Winstanley 200I).

De Lopez (2OOI: 48) explains that, 'stakeholder management essentially consists of understanding and predicting the behavior and actions of stakeholders and devising strategies to ethically and effectively deal with them'.

All stakeholders do not need to be involved equally in the decision making process, but it does require that all interests are identified and understood (Donaldson \& Preston 1995). Failure to identify the interest of even a single primary stakeholder group may result in the failure of the process (Clarkson I995).

Proper stakeholder involvement has multiple outcomes depending on the process used and the stakeholders. The outcomes of involvement include:

- Information and education of public about the topics and issues (Beierle I998; Simrell King \& Feltey 1998);

- Public values and opinions are incorporated in the decision making process (Beierle I998; Carmin, Darnall, \& Mil- Homens 2003);

- The improvement of quality of the decisions (Beierle I998; Fiorino I990);

- New ideas are generated (Carmin, Darnall, \& Mil-Homens 2003; Fiorino I990; Steelman 2OOI);

- Ensuring that stakeholders in tourism are treated fairly (Beierle I998; Carmin, Darnall, \& Mil-Homens 2003; La Porte \& Metlay 1996; Simrell King \& Feltey I998);

- Being ethics towards the host community and tourists (Beierle I998; Carmin, Darnall, \& Mil- Homens 2003; Simrell King \& Feltey 1998; Steelman 2OOI);

- A effective cost process (Beierle I998);

- Each stakeholder has the rights and possibilities (Carmin, Darnall, Mil-Homens 20O3).

\section{Sustainable Tourism in Albania, especially in Shkodra Region}

Tourism has been recognized as one of the driving forces of Albania's economy - providing jobs and income to thousands of families. And travel and tourism affects all sectors of Albania's economy, stimulating the growth of small and medium-sized enterprises in other sectors- creating more jobs and income along the way. According to the 2008 World Travel \& Tourism Council report, Albania's travel and tourism economy directly and indirectly 
accounted for SI.8 billion, equivalent to almost I5 \% of the Albania's GDP, and employed almost I5O,OOO jobs or I2\% of the total employment.

Albania has unique ecological features that provide significant but under-utilized tourism potential, including coastal areas, mountainous terrain, rivers, parks, and protected areas. The tourism industry in Albania currently focuses on coastal areas, rather than on the unique features that set this country apart from its neighbors. Albania's natural features have the potential to attract tourists seeking ecological and cultural experiences. Thoughtful, sustainable development of these resources could enhance community livelihoods throughout Albania.

This study is concentrated in the sustainable tourism development in Shkodra Region, because it is one of the biggest northern cities of Albania. It is often called as the main northern city. Shkodra Region has a lot of opportunities to develop different kind of tourism, because of the extraordinary geographical position and for the cultural heritage it possesses. These potentials give her the possibility to develop different types of tourism:

- Seaside tourism in the Velipoja zone - only $30 \mathrm{~km}$ away from the city;

- City tourism - having a high number of cultural and historical monuments, about 90;

- Lake tourism - it is positioned on the shore of the biggest lake in the Balkan (Shkodra lake);

- Mountain tourism (or white tourism) - concentrated in the beautiful zones of Theth and Razem, only $46 \mathrm{~km}$ away from the city.

The fact that Albania is interested seriously about sustainable tourism as a means of economic development puts them ahead of many nearby countries that followed the path of mass tourism development, which has left behind damaged ecosystems, polluted beaches, and vanishing local culture. While uncontrolled tourism has already spread to some parts of Albania, much of the rest of the country, especially Shkodra Region still offers a chance to experience traditional Mediterranean life that has become increasingly rare in the Region. Albania plans it right-and a growing number of Albanians are calling for sustainable tourism development to avoid the mistakes of tourism gone wrong in other parts of the Mediterranean.

According to Strategic Plan for Economic development of Shkodra municipality, 2005 $2 \mathrm{OI} 5$ the vision is "Development and preservation of the cultural, historical and artistic traditions and values of Shkodra and their promotion to the benefit of tourism development."

The principle of sustainable tourism development is the guiding principle to build this sector. In doing so, Shkodra Region has chosen a difficult path, but the right one, that in the long-term will preserve Shkodra's cultural heritage, conserve natural resources, protect precious archeological and historical monuments, and improve livelihoods. In practice, the principle is a difficult one to implement because sustainable development requires significant planning, visionary leadership, great coordination, and concerted action at every level to produce results felt and understood by people.

To make sustainable tourism a reality in Albania, and especially in Shkodra Region coordinated efforts among all stakeholders, as well as, a strong, practical action plan are indeed necessary.

\section{Research Methodology}

The comparative study involved questionnaire-based surveys of tourists, residents, business owners, and local government officials undertaken in the Shkodra Region. 
Data were collected from stakeholders using a self competed questionnaire, which included Likert-style questions inquiring about attitudes and perceptions of sustainable tourism development in the community.

The survey of tourists visiting the Shkodra Region was conducted in the summer 2009. The questionnaire was reviewed by a local-background group of authorities, managers and planners, tourist industry and non-government organizations, and pre-tested by IO tourists in the area. We personally contacted tourists at Shkodra city, Shiroka, Zogaj and Velipoja beach throughout the area during the 7 - week survey period. Contact points reflected the geographical distribution and a variety of natural and cultural settings. This sampling was chosen to include tourists and one- day tourists (excursionist) and tourists visiting family and friends. Tourists received a verbal introduction and a self completed questionnaire. Of the remaining I5O tourists, I23 agreed to participate. Given the high response rate and representation of many tourism different areas, the sample was considered to be the representative of tourists in the area.

The survey of local residents in the Shkodra Region was conducted in the summer 2009. A statistically random sample of the adult population aged between I5 and 79 years was drawn. The questionnaire was reviewed by the local-background group and pre-tested by four local residents. Questionnaires were self completed. Of the remaining I5O residents, 7 refused to answer.

The sample of the business owners was random and included 30 tourism business owners (hotels, bar/restaurants, travel agencies, etc), and others the owners of taxi services, retailing, fuel points, construction, etc.

The sample of local government officials was no-random. We interviewed the tourism and environment specialists of Shkodra Region, Shkodra Municipality, Shkodra Prefecture and Velipoja Commune

\section{Results and finding}

Despite the stakeholder specific nature, each interview shared three principal commonalities. Initially, each interview attempted to acquire the stakeholder's general understanding and interpretation of the term 'sustainable tourism development'.

The aim of the questioning was to give the respondents sample opportunity to fully express their viewpoints around the development of sustainable tourism.

The respondents were asked about how important (on a three-position scale: high importance, some importance and no importance) they felt the principles of sustainable tourism were. In addition, respondents were asked to rate the overall importance of the work on developing sustainable tourism in the area. As seen in Fig.I local government officials and tourists found the overall work on sustainability of significant higher importance than did local residents and business owners.

$70 \%$ of local government officials and $62 \%$ of tourists viewed the work as being of high importance, $40 \%$ of local residents and $45 \%$ of business owners found the sustainability work of high importance. IO-20\% in all groups found the work of no importance.

To facilitate the process of data analysis we created two groups. The first group included tourists and second group called host community included the residents, business owners, and local government officials. Respondents were asked to rate according to Likert scale the importance (very important, somewhat important and not important) of each of the I2 principles of sustainable tourism. 


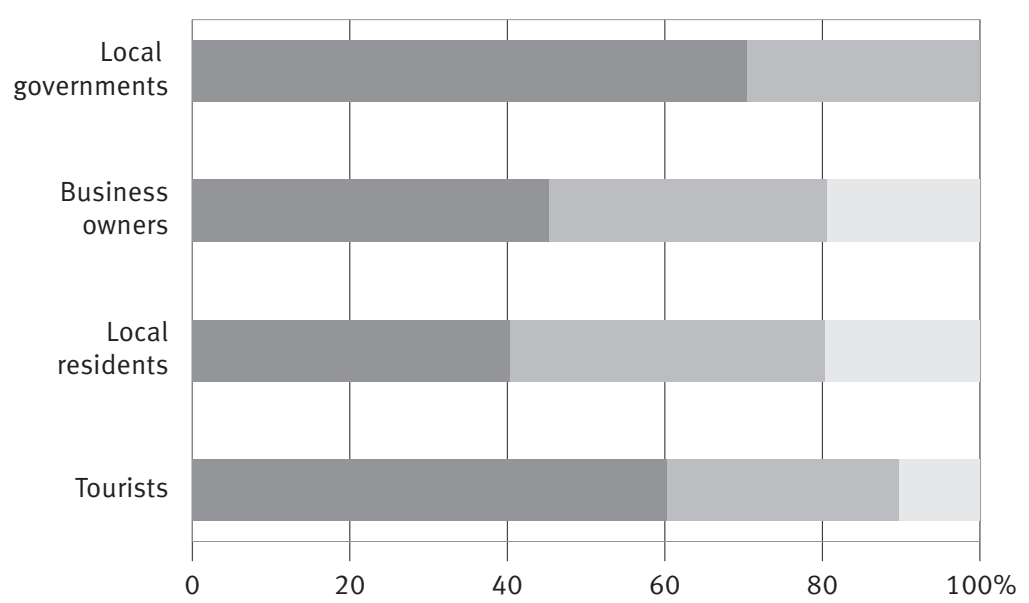

Figure 1. The perceptions of tourists and host community of the overall importance of the works towards establishing sustainable tourism principles

The majority of tourists and host community found the principles of sustainable tourism to be of high or some importance.

While tourists and host community had a similar ranking of the top priorities, some differences are found in relation to the economic and planning principles. Tourists found their own contributions to the improvements of the destination to be of the lowest importance, while host community gives the lowest priority to the integration of tourism into local, Regional and national planning.

Tourists generally find the principles more important than do host community. Tourists were significantly more interested than host community in consulting different interests group in the development of environmental education of personnel in tourism areas (40-70\%), environmental considerations in marketing of tourism (35-68\%), involvement of

Table 1. Sustainability principles included in the study (after Kaae, 2001)

\begin{tabular}{|l|l|}
\hline Sustainability principle & Primary focus \\
\hline Support of local economy & Economic \\
\hline Tourism supports improvements in the area & Economic \\
\hline Cooperation with local residents & Local participation \\
\hline Consultation of interest groups including stakeholders & Local participation \\
\hline Integration of tourism into local, Regional and national planning & Planning \\
\hline Sensible use of nature resources & Environmental \\
\hline Reduction of consumption and waste products & Environmental \\
\hline Maintain diversity of plants and animals & Environmental \\
\hline Studies of environmental and social impacts & Environmental and social \\
\hline Responsible marketing of tourism & Environmental and social \\
\hline Information and nature interpretation for tourists & Educational \\
\hline Training of staff & Educational \\
\hline
\end{tabular}




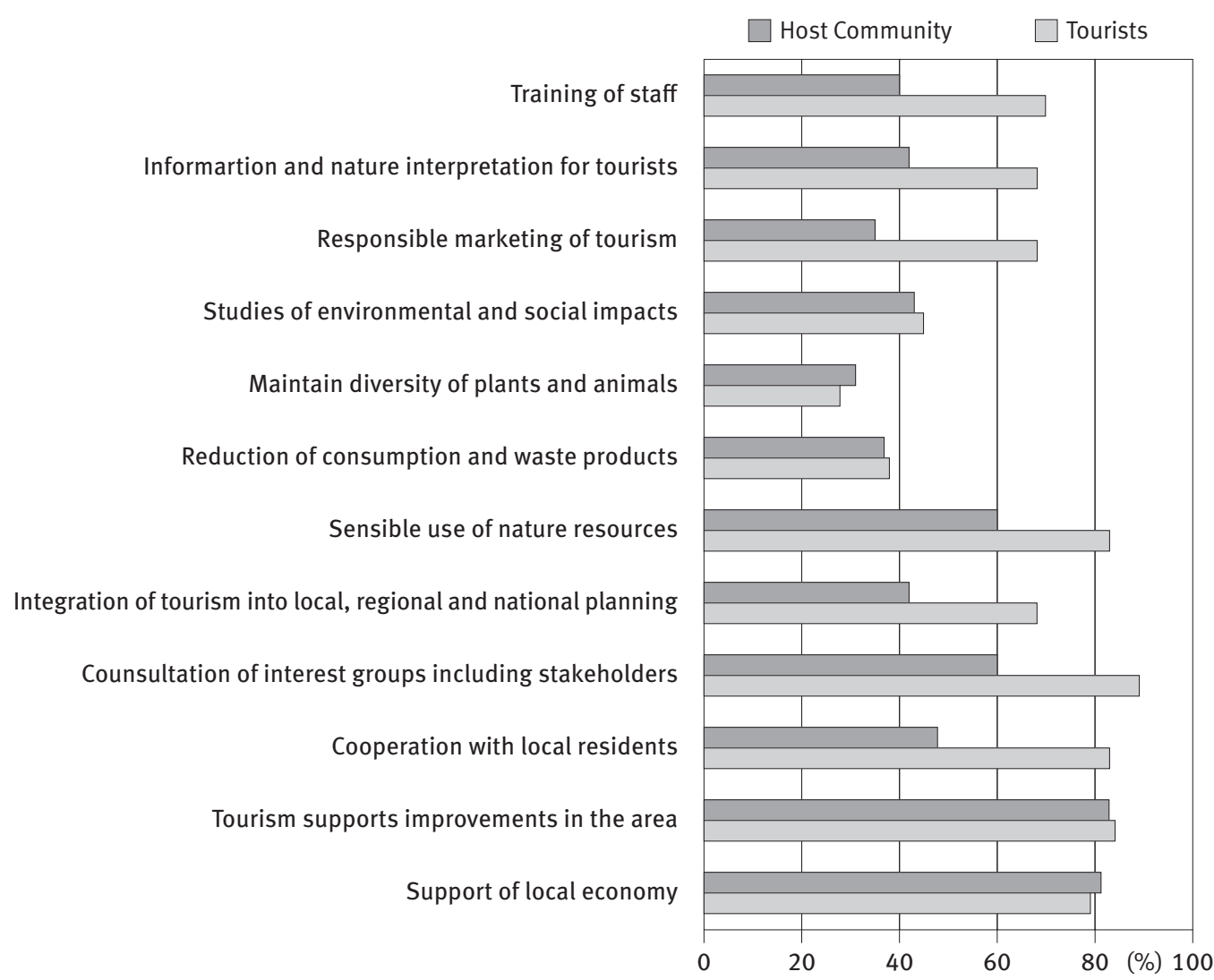

Figure 2. The perceptions of tourists and host community according to high importance of sustainable tourism principles

interest groups in tourism development (6O-89\%), and sensible use of natural resources (6O$83 \%)$.

The higher interest among tourists was less significant in relation to conduction of studies of tourism impact on the environment and local communities (45\%), and reduction of waste, energy consumption, water consumption and wastewater (38\%). No significant differences were found in tourists' and host community' interests in economic benefits to the local economy from tourism, contributions by tourists to the improvements in the area, maintaining the diversity of animals and plants, and information to tourists about the natural and cultural qualities of the area,

The most differing opinions were found in relation to cooperation with local residents in the development of tourism, which $83 \%$ of tourists find of high importance compared to only $48 \%$ of the host community. The integration of tourism into local, Regional and national planning was of high importance to $68 \%$ of the tourists and $42 \%$ of host community.

Based on Butler's (1980) resort life cycle, on our observations and the results of our questionnaires we concluded in following matrix:

Thus, each stakeholder group has different goals and perspective towards sustainable tourism development and this is a challenge for sustainability.

In Shkodra Region the tourism is in its infancy. Certain players, among them the local authority and a small number of private investors, gradually realize that tourism can fuel 
Table 2. Agenda of Conflicting development of Sustainable tourism

\begin{tabular}{|l|l|l|l|l|}
\hline Agenda & $\begin{array}{l}\text { Local government } \\
\text { officials }\end{array}$ & Residents & $\begin{array}{l}\text { Business owners } \\
\text { (hoteliers) }\end{array}$ & $\begin{array}{l}\text { Business owners } \\
\text { (others) }\end{array}$ \\
\hline Visibility & Low & High & High & Low \\
\hline $\begin{array}{l}\text { Environmental } \\
\text { priority }\end{array}$ & Low & Mixed & Low & Low \\
\hline $\begin{array}{l}\text { Socio-cultural } \\
\text { priority }\end{array}$ & Medium & Low & Low \\
\hline $\begin{array}{l}\text { Support for } \\
\text { regulations }\end{array}$ & Emerging & Low & Low & Low \\
\hline Tourism strategy & $\begin{array}{l}\text { Provide incentives/ } \\
\text { laissez faire }\end{array}$ & $\begin{array}{l}\text { Support } \\
\text { fast growth } \\
\text { development }\end{array}$ & $\begin{array}{l}\text { Support } \\
\text { fast growth } \\
\text { development } \\
\text { / speculative } \\
\text { building }\end{array}$ & $\begin{array}{l}\text { Support } \\
\text { fast growth } \\
\text { development }\end{array}$ \\
\hline
\end{tabular}

rapid economic growth. Thus, there is pressure by some stakeholders to create an atmosphere conductive to investment for tourism related activities.

The residents have positive attitudes towards tourism development, because associate it with the creation of jobs, wealth creation, etc and demonstrate little opposition to the sector.

These local players are not too concerned about environmental issues.

The sustainable tourism development requires the regarding of the stakeholders' interests. The collaboration among key players is a fundamental ingredient in sustainable development efforts. The stakeholder management creates the stability into the tourism, environment and societal affiliation.

\section{Conclusion}

As the result of the comparisons of perceptions of sustainable tourism development and principles in Shkodra Region between stakeholder group the study concludes that there is a considerably difference among them.

The only way for Shkodra Region to succeed in developing more sustainable forms of tourism will mean all stakeholders in tourism working together. The adopting and implementing the principles of sustainable development through effective partnerships and practices, success in achieving sustainable tourism development can be realized.

All stakeholders should have the opportunity to have the same level of knowledge/ understanding of the issues. This may require that specific stakeholders be given opportunities for education about the topics that are to be addressed in the decision making process. Once everyone in the process has the same level of knowledge, decisions can be made that utilizes the collective wisdom of all the stakeholders.

The host community in Shkodra Region needs to develop the concept of "fair trade" in tourism. This implies a more direct role for communities and government in dealing with tourists directly rather than using intermediaries such as foreign tour operators who take a share of the benefits. 


\section{References}

Andereck, K. L. and Vogt, C. A. (2000). The Relationship between Residents Attitudes toward Tourism and Tourism Development Options, Journal of Travel Research, 39, 27 - 36.

Beeton, R.J.S., \& Hardy, A.L. (2001). Sustainable Tourism or Maintainable Tourism: Managing Resources for More Than Average Outcomes. Journal of Sustainable Tourism, 9 (3), 168-192.

Beierle, T.C. \& Konisky, D.M. (2000). Values, conflict, and trust in participatory environmental planning. Journal of Policy Analysis and Management, 19 (4), 587-602.

Beierle, T.C. (1998). Public participation in environmental decisions: An evaluation framework using social goals. Washington DC: Resources for the Future.

Berry, S., \& Ladkin, A. (1997). Sustainable tourism: a Regional perspective. Tourism Management, 18 (7), 433-440.

Brunt, P. and Courtney, P. (1999), Host Perceptions of Sociocultural Impacts, Annals of Tourism Research, 26, 3, 493 - 515.

Butler, R., Hall, C. and Jenkins, J. (1998). Introduction, in Butler, R., Hall, C. and Jenkins, J. (eds), Tourism and Recreation in Rural Areas, John Wiley and Sons Ltd, New York, NY, pp. 3-16.

Carmin, J., Darnall, N. \& Mil-Homens, J. (2003). Stakeholder involvement in the design of U.S. voluntary environmental programs: Does sponsorship matter? Policy Studies Journal, 31 (4), 527- 543.

Choi, H.C. \& Sirakaya, E. (2006). Sustainability indicators for managing community tourism. Tourism Management, 27, 1274-1289.

Clarkson, M. B. E. (1995). A stakeholder framework for analyzing and evaluation corporate social performance. The Academy of Management Review, 20 (1), 92-117.

Davis, J. S. and Morais, D. B. (2004). Factions and Enclaves: Small towns and socially Unsustainable Tourism Development. Journal of Travel Research. 43 (1), 3-10.

De Lopez, T. T. (2OOI). Stakeholder Management for Conservation Projects: A case study of Ream National Park, Cambodia, Environmental Management, 28, I, 47-60.

De Oliveira, JAP (2003). Governmental Responses to Tourism Development: Three Brazilian case studies, Tourism Management, 24, 97-IIO.

Donaldson, T. \& Preston, L.E. (I995). The stakeholder theory of the corporation: Concepts, evidence, and implications. The Academy of Management Review, $2 \mathrm{O}$ (I), 65-9I.

Fiorino, D.J. (1990). Citizen participation and environmental risk: A survey of institutional mechanisms. Science, Technology, \& Human Values, I5 (2), 226-243.

Freeman, R.E. (1984). Strategic management: A stakeholder approach. Boston: Pitman.

Godfrey, K.B. (I998). Attitudes towards 'sustainable tourism' in the UK: a view from local government. Tourism Management, I9 (3), 213-224.

Gunn, C.A. (1994). Tourism planning: Basic concepts cases (3rd ed.). Washington, D.C.: Taylor and Francis.

Hardy, A. L. and Beeton, R. J. S. (2OOI) Sustainable Tourism or Maintainable Tourism: Managing resources for more than average outcomes, Journal of Sustainable Tourism, 9, 3, I68-I92.

Healey, P. (1998). Collaborative planning in a stakeholder society. Town Planning Review, 69, I-2I.

Holden, A. (200I). Environment and Tourism. London: Routledge.

Inskeep, E. (I99I). Tourism Planning: An Integrated and Sustainable Development Approach, New York: Van Nostrand Reinhold. 
Ioannides, D. (I995). A flawed implementation of sustainable tourism; the experience of Akamas, Cyprus. Tourism Management I6 (8), 583-592.

Jones, T. M. (1995). Instrumental stakeholder theory: A synthesis of ethics and economics. The Academy of Management Review, $2 \mathrm{O}$ (2), 404-437.

Kaae, B. (2OOI). The perceptions of tourists and residents of sustainable tourism principles,in McCool,S.F\&Moisey,R. (eds), Tourism, Recreation and Sustainability, Cabi Publishing, 289-3I5

Lett, J. (1989). Epilogue to touristic studies in anthropological perspective. In V. Smith (Ed.), Hosts and Guests: The Anthropology of Tourism (2nd ed.) (pp.265-279). Philadelphia: University of Pennsylvania Press.

Long, P., Perdue, R. and Allen, L. (I990) Rural Residents Perceptions and Attitudes by Community Level of Tourism, Journal of Travel Research, 28, 3, 3-9.

Martin, S.R. (1995). Montanans Attitudes and Behavioural Intentions toward Tourism: Implications for sustainability, in McCool, S. F. and Watson, A.E. (eds), Linking Tourism, the Environment, and Sustainability - Topical volume of compiled papers from a special session of the Annual Meeting of the National Recreation and Park Association ', Intermountain Research Station, Ogden, UT, pp. 69-76

Matheson, A. and Wall, G. (I982) Tourism: Economic, physical, and social impacts, John Wiley and Sons, Inc, New York.

McCool, S.F. (1995). Linking tourism, the environment and concepts of sustainability: setting the stage. In McCool, S.F., Watson, A.E. comps, I995. Linking tourism the environment and sustainability - topical volume of compiled papers from a special session of the annual meeting of the National Recreation and Park Association. 3-7.

Municipality of Shkodra (2006). Strategic Plan for Economic Development 2005 - 2015.

Murphy, P. E. (1983) Perceptions and Attitudes of Decision Making Groups in Tourism Centers, Journal of Travel Research, 2I, 3, 8-I2.

Pizam, A., Uriely, N. and Reichel, A. (2000). The Intensity of Tourist-Host Social Relationship and its Effects on Satisfaction and Change of Attitudes: The case of working tourist in Israel, Tourism Management, 2I, 395-406

Pucako, L. and Ratz, T. (2000). Tourist and Residents Perceptions of Physical Impacts of Tourism at Lake Balaton, Hungary: Issues for sustainable tourism management', Journal of Sustainable Tourism, 8, 6, 458-478.

Robson, J. \&Robson, I. (I996). From shareholders to stakeholders: critical issues for tourism marketers. Tourism Management, I7 (7), 533-540.

Simrell King, C., Feltey, K.M. (I998). The question of participation: Toward authentic public participation in public administration. Public Administration Review, 58 (4), 3I7-326.

Southgate,C.\&Sharpley, R. (20O2). Tourism, Development and the Environment, in Sharpley, R. and Telfer, D. J. (eds), Tourism and Development: Concepts and issues, Channel View Publications, Clevelan, 23I-262.

Steelman, T. A. (2OOI). Elite and participatory policymaking: Finding balance in a case of national forest planning. Policy Studies Journal, 29 (I), 7I-89.

UNEP\&WTO (2005). Making Tourism More Sustainable: A Guide for Policy Makers. Retrieved: I5.09.05 from UNEP Tourism: Publications: http://www.uneptie.org/pc/ tourism/documents/Making\%2OTourism\%2OMore\%2OSustainableA\%2OGuide\%2O for\%2OPolicy\%2OMakers/making\%2Otourism\%2Omore\%2Osustainable\%2OpartI.pdf

Weaver, D.B. (2000). A broad context model of destination development scenarios. Tourism Management, 2I, 2I7-224. 
Wilson, S., Fesenmaier, D., Fesenmaier, J. and Van Es, J. (2OOI) Factors for Success in Rural Tourism Development, Journal of Travel Research, 4O, I32-I38

World Commission on Environment and Development. (1987). Our common future, Oxford: Oxford University Press.

World Tourism Organization. (2004). Concepts and Definitions of Sustainable Development of Tourism by the World Tourism Organization', retrieved IIth March, 2008, from the World Wide Web: http://www.world-tourism.org/frameset/frame_sustainable.html. WWF (2004). WWF-UK Research Centre: Tourism. Retrieved: I2.II.O4 from http://www. wwf.org.uk/researcher/issues/Tourism/index.asp

Yuksel, F., Bramwell, B. and Yuksel, A. (1999). Stakeholder Interviews and Tourism Planning at Pamukkale, Turkey, Tourism Management, 2O, 35I-360. cial 